\title{
東北地方の降雪分布に関する総観気候学的研究
}

\section{黒 坂 裕 之*}

\begin{abstract}
東北地方の降雪分布についての研究は，北陸地方の降雪分布の研究ほど十分には行なわれていない．本論 文では，まず東北地方の降雪分布型を求め，次にその分布型に対応する総観規模天気図の特徴を明らかに する. 日降雪量 $10 \mathrm{~cm}$ 以上の日を多降雪日とし, 多降雪日の出現の状態から地域区分を行ない, 分布の中 心が現われる地域の違いによって，分布型を分類した. 分類された降雪分布型と総観規模天気図，特に 850 $\mathrm{mb}$ 面天気図との対応を明らかにする. 日本海側に分布の中心をもつ分布型は, $850 \mathrm{mb}$ 面の気流との対応 が明瞭である. 太平洋側に分布の中心をもつ分布型は, $850 \mathrm{mb}$ 面低気圧の中心位置との関係が明瞭である. 低気圧にともなう上昇流域との関係から，太平洋側の降雪は低気圧による降雪であるといえる。
\end{abstract}

\section{I はじめに}

降雪分布や降雪機構の研究は, 北陸地方や石狩平 野にふった大雪を中心として行なわれてきた．北陸 地方の大雪はその分布の違いから里雪と山雪に分け られ，その特徴については深石(1963)が明らかにし た. 里雪発生の総観場の条件は Fukuda (1965) が明 らかにし，藤田(1966)は里雪と山雪の総観状態の相 違を地上天気図・ $500 \mathrm{mb}$ 天気図の特徴から明らか にした. Matsumoto et al.(1967)や Miyazawa (1967) は豪雪時の総観気象学的解析を行ない, 豪雪時の中 規模じょう乱の構造とその役割を明らかにした．里 雪の降雪機構については，「北陸豪雪調査報告」 (気象庁，1968)にまとめられている.一方，石狩平 野の大雪については，長谷川(1949)が石狩湾小低気 圧によると指摘し, その後, 衛星写真やレーダーを 使用した研究が行なわれている. 岡林(1966)は高層 の気温状態を比較すると，両地域での大雪機構には 本質的な差はないとしている.

東北地方における降雪機構の研究の主体は, 県単 位での大雪予報を目的とする研究がほとんどであっ た(川添，1973)。また，地域的にも日本海側の県に 限られていた．太平洋側の雪に関しては，岩手県に 関する統計調查 (工藤・中村, 1976)や台湾低気圧に

\footnotetext{
* 筑波大学・院
}

よる降水分布の研究（田坂，1977)があるにすぎない． このように，東北地方の降雪に関する研究は対象 とする量・地域ともに限られていた，そこで，本論 文では，東北地方全域(新潟県北部を含む)を対象と して降雪分布型を分類し，それに対応する総観的状 態を記述することを目的とする。

\section{II 降雪分布型の決定方法}

第 1 図に観測地点の分布を示す. 用いた資料は各 県の農業気像月報, 気像庁発行の天気図である. 本 論文では積雪深の差をもって日降雪量とした. 対象 期間は 1971 年 12 月から 1975 年 3 月までの 4 冬期, 各 4 か月である.

総観規模の現象と降雪分布とを対応させるために しゅう雪によるとみられる日降雪量 $10 \mathrm{~cm}$ 以下の 降雪については研究対象としなかった，日降雪量 $10 \mathrm{~cm}$ という值は, 秋田県平野部の日降雪量出現確 率からみると多降雪に属する(佐々木, 1971)。以下， $10 \mathrm{~cm}$ 以上の日降雪量を観測した日を多降雪日と呼 び, 多降雪日の出現の状態から, 対象地域を区分し た. まず，対象地域内に均等に分布するように基準 とする点を 65 地点設定した(第 1 図の大きい黒丸). 任意の観測点が基準点と同じ日に多降雪日であった 日数の出現率を求めた．例として，新庄を基準点と した場合の出現率の分布を第 2 図に示す. 図中の太 


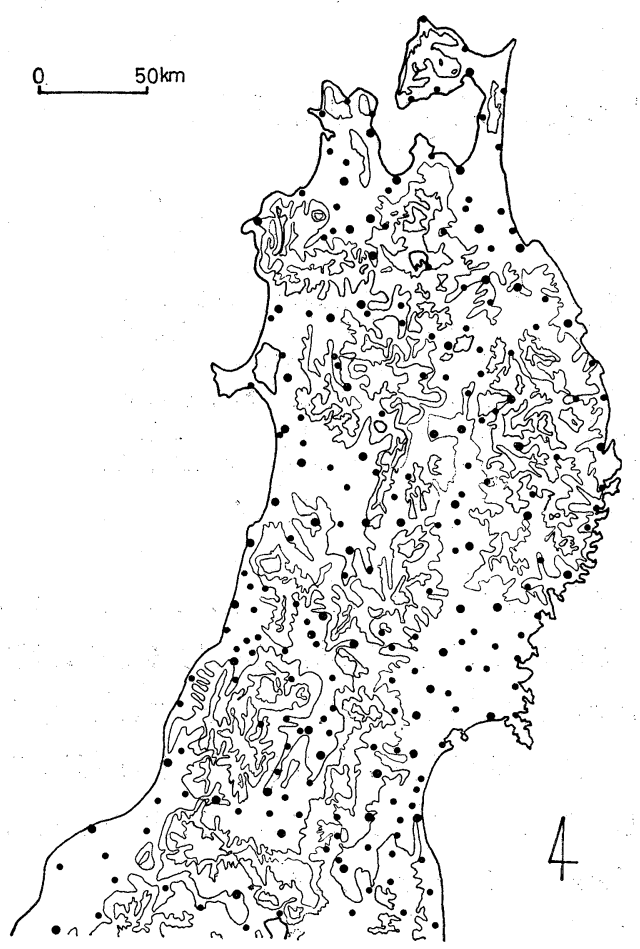

第 1図 観測地点の分布

大きい黑丸は地域区分に用いた基準点を示す．地形の 概要は $200 \mathrm{~m}, 600 \mathrm{~m}, 1,000 \mathrm{~m}$ の等高線で表わした.

い実線は出現率が $20 \mathrm{~km}$ 当たり $20 \%$ 以上変化して いる地域の中心線である. このように出現率が大き く変化する地域は，ある基準点と類似の原因による 降雪の境界地域，すなわち，ある種の天気界と考え られる. 第 2 図によれば, 新庄と山形とは異なる多 降雪日の出現についての特性をもつものであること が示唆される. 新庄が多降雪日であっても, 山形で は多降雪日となることは少ない，新庄と山形との天 気の差違については菊地(1972)の指摘があり，新庄 と山形の天気は対照的であると述べられている.

新庄を基準点とした場合と同様にして，他の 64 の基準点についても, 境界地域が求められる. 多降 雪日出現率の 65 枚の分布図で求められた，境界地 域の中心線の合成図を作成し，合成図上に $20 \times 20$ $\mathrm{km}$ のメッシュをかけ, メッシュ内にみられる中心 線の本数に関する分布図を作成した. この分布図に

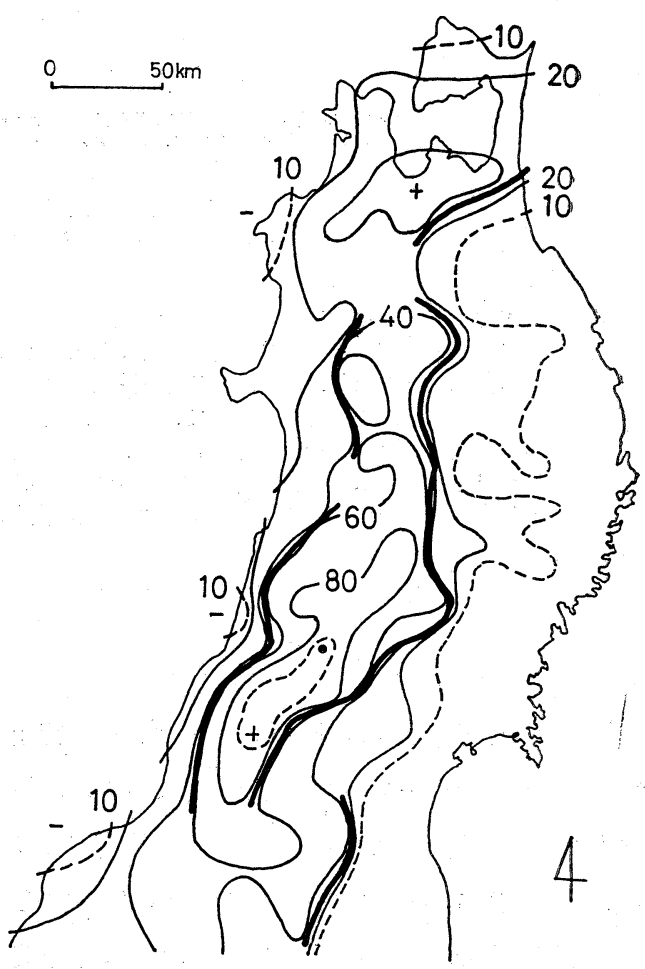

第 2 図多降雪日の出現率の分布 (基準点を新 庄とした場合)

黒丸は基準点 (新庄)を示す. 細線は出現率 (\%)を， 太線は境界地域の中心線を示す。

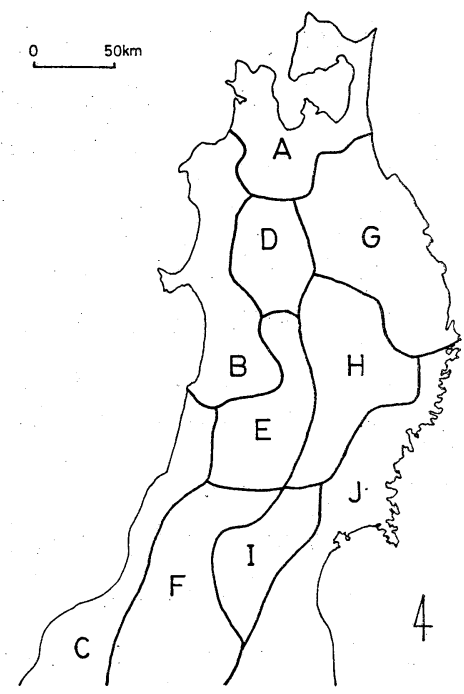

第 3 図、多降雪日の出現状態に基づいた地域区分 
おける極大域をもって地域区分線とし，地域区分を 行なった. その結果は第 3 図のとおりである.

Shitara (1966)は曇天日と降雪日の出現の天気界 から，東北地方の地域区分を行なっている. 今回の 結果と Shitara の結果を比較すると, 日本海側・太 平洋側の海岸部においてはほぼ一致している.これ は, 海岸部での降雪は降雪日数が少なく，降雪があ る場合には多降雪日となりやすいためと考えられる. 次に, 毎日の日降雪分布図の中で, 最深值の地点 を含み，かつその $50 \%$ 以上の降雪量の地域(以下, この地域を中心域と呼ぶが，上述のように分類さ れた地域のどれに属するかで, 降雪分布図を分類し た. ただし，三瓶・川添(1976)が指摘するように東 北地方の降雪分布は北陸地方ほど明瞭に山雪・里雪 が分けられるわけではない，そこで，海岸部におい て相対的に多雪となる場合を海岸部の降雪型と認定 したＡ地域に日降雪分布図中の中心域が含まれる
場合を $\mathrm{A}$ 型と名づけた，他の型についても同様であ る. 分類が困難である場合をX型，全地点で多降雪 日とならなかった場合を $\mathrm{O}$ 型として，分類したた た だし，今回はX型，O型については研究の対象とは しない.

\section{III 地上気圧配置型別の降雪分布型の出現日数}

第 1 表は 4 冬期における降雪分布型の地上気圧配 置型別の出現日数と出現頻度を示したものである. 気圧配置型の分類については, Yoshino and Kai (1974)を参考にし，各型の基準を次のとおり定めた.

I 型 : 西高東低の冬型の気圧配置型

而型 : 低気圧型

$$
\begin{aligned}
& \mathrm{a}: \text { 北海道または樺太に低気圧 } \\
& \mathrm{b}: \text { 日本海上に低気圧 } \\
& \mathrm{c}: \text { 太平洋岸に低気圧 } \\
& \mathrm{d}: \text { 二つ玉低気圧 }
\end{aligned}
$$

第 1 表降雪分布型の地上気圧配置型別出現日数

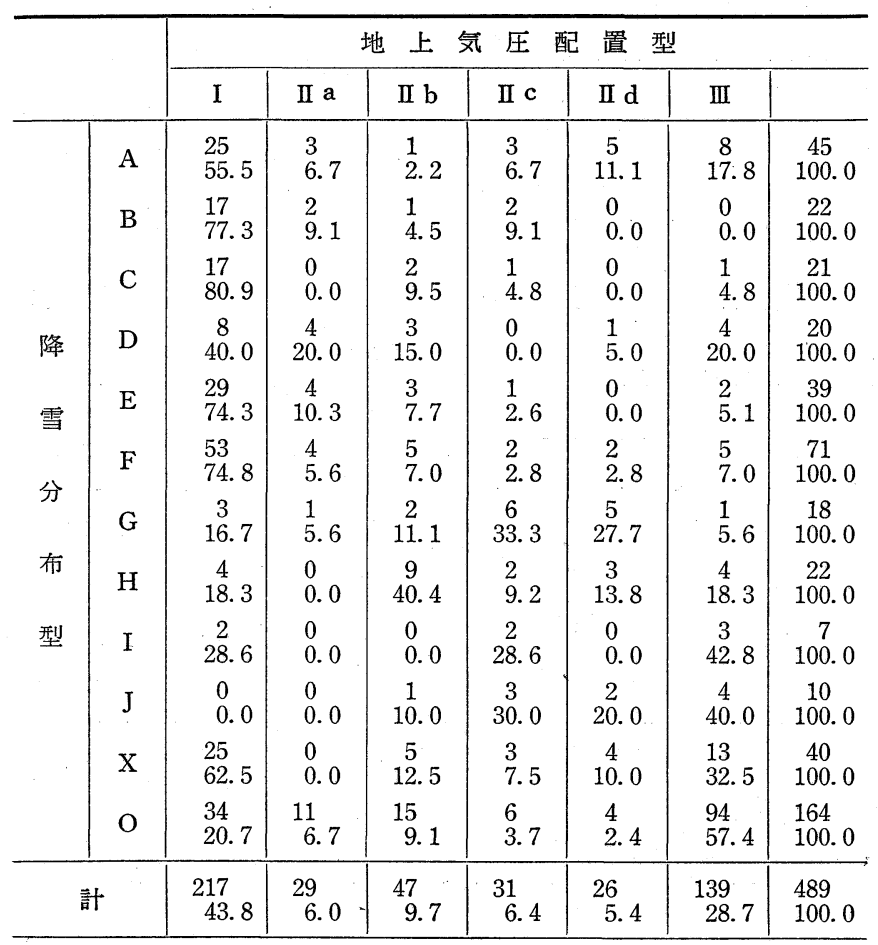

上段は出現日数, 下段は出現頻度を示す. 
III型 : その他の型

以上の基準に基づいて, 気象庁発行の 9 時の地上天 気図を分類し，降雪分布型に集計したものが第 1 表 である. この表の最下欄にはさらに 4 冬期の地上気 圧配置型の総出現日数をも示してある.

$\mathrm{A} \sim \mathrm{F}$ 型においては I 型の出現する頻度が最も高 い. 特に， B・C・E・F型では $70 \sim 80 \%$ である. 一方，G〜J 型ではII型の出現頻度が高いが，同じ II 型であっても，降雪分布型の相違は低気圧の位置 の違いを反映している． G・J 型ではII c 型の出現 頻度が高いのに対し，H型ではII b 型の出現頻度が 高くなっている. このようなことから降雪分布型の
$\mathrm{A} \sim \mathrm{F}$ 型は気圧配置型の I 型に， $\mathrm{G} \sim \mathrm{J}$ 型は II 型に それぞれ対応しているといえる。

$\mathrm{I} \cdot \mathrm{J}$ 型についてみると，正型での出現頻度が比 較的高くなっている．9時の地上天気図では，低気 圧が西方にあって，気圧配置型は而型に分類されて いる. しかし，その低気圧の移動速度が大きいため. に，同日のうちに東北地方南部がその影響圈に入っ たものと考えられる. 田坂(1977)の図によると，低 気圧が $130^{\circ} \mathrm{E}$ から $140^{\circ} \mathrm{E}$ の範囲にある時に，東北 地方南部太平洋岸は降水域となっている. そこで,

$I ・ J$ 型の翌日 9 時の地上気圧配置型をみると，両 型とも II c 型の出現頻度が大きく増加している.こ

第 2 表 翌日に出現する降雪分布型の出現率

\begin{tabular}{|c|c|c|c|c|c|c|c|c|c|c|c|c|c|}
\hline & \multicolumn{4}{|r|}{ 翌 } & \multirow{2}{*}{$\begin{array}{c}\text { 日 } \\
E\end{array}$} & \multirow{2}{*}{$\frac{\text { の }}{\mathrm{F}}$} & \multirow{2}{*}{$\frac{\text { 分 }}{G}$} & \multirow{2}{*}{$\frac{\text { 布 }}{\mathrm{H}}$} & \multicolumn{4}{|l|}{ 型 } \\
\hline & & A & B & C & D & & & & & I & $\mathrm{J}$ & $\mathrm{X}$ & $\mathrm{O}$ \\
\hline \multirow[b]{4}{*}{ 当 } & A & 40.0 & 6.7 & 2.2 & 6.7 & 4.4 & 8.9 & 2.2 & 4. 4 & - & 2.2 & 8.9 & 13.4 \\
\hline & B & 13.6 & 9.1 & 9.1 & 9.1 & 4.5 & 22.8 & 4.5 & - & 9.1 & - & 9.1 & 9.1 \\
\hline & $\mathrm{C}$ & 14.2 & 9.5 & 28.6 & - & 9.5 & 28.6 & - & - & - & - & 4. 8 & 4.8 \\
\hline & $\mathrm{D}$ & 10.0 & - & - & 5.0 & 20.0 & 20.0 & 5.0 & 5.0 & - & - & 15.0 & 20.0 \\
\hline 日 & $\mathrm{E}$ & 10.5 & 10.5 & 5.3 & 2.6 & 10.5 & 23.7 & - & 5.3 & 2.6 & 2.6 & 13.2 & 13.2 \\
\hline の & $\mathrm{F}$ & 5.6 & 4.2 & 8.5 & 5.6 & 14.1 & 32.4 & - & 2.8 & 1.4 & 1.4 & 8.5 & 15.5 \\
\hline \multirow{3}{*}{ 分 } & $\mathrm{G}$ & 5.8 & 11.9 & 5.8 & - & 5.8 & 5.8 & 23.7 & - & 5.8 & 5.8 & 11.9 & 17.7 \\
\hline & $\mathrm{H}$ & - & 13.6 & 9.1 & - & 13.6 & 9.1 & 4.5 & 27.4 & - & - & 13.6 & 9.1 \\
\hline & I & 14.3 & 14.3 & - & - & - & 42.8 & - & - & - & - & 28.6 & - \\
\hline \multirow[t]{3}{*}{ 型 } & $\mathbf{J}$ & 30.0 & - & 10.0 & - & - & - & - & 20.0 & - & 10.0 & 30.0 & - \\
\hline & $\mathrm{X}$ & 4. 0 & 4.0 & - & 4.0 & 8.0 & 14.0 & 4.0 & 2.0 & 2.0 & - & 16.0 & 42.0 \\
\hline & $\mathrm{O}$ & 5.6 & - & - & 4. 4 & 5.1 & 6.3 & 3.2 & 3.2 & 0.6 & 3.2 & 7.0 & 64.6 \\
\hline
\end{tabular}

第3 表 前日に出現した降雪分布型の出現率

\begin{tabular}{|c|c|c|c|c|c|c|c|c|c|c|c|c|c|}
\hline & \multicolumn{4}{|r|}{ 前 } & \multirow{2}{*}{$\frac{\text { 日 }}{\mathrm{E}}$} & \multirow{2}{*}{$\frac{\text { の }}{F}$} & \multirow[t]{2}{*}{ 分 } & \multirow{2}{*}{$\frac{\text { 布 }}{\mathrm{H}}$} & \multicolumn{4}{|l|}{ 型 } \\
\hline & & A & B & C & D & & & & & I & $\mathrm{J}$ & $\mathrm{X}$ & $\mathrm{O}$ \\
\hline \multirow{4}{*}{ 当 } & A & 40.0 & 6.7 & 6.7 & 4. 4 & 8.9 & 8.9 & 2.2 & - & 2.2 & 6.7 & 4. 4 & 8.9 \\
\hline & B & 13.6 & 9.1 & 9.1 & - & 18.3 & 13.6 & 9.1 & 13.6 & 4.5 & - & 9.1 & - \\
\hline & $\mathrm{C}$ & 4.8 & 9.5 & 28.6 & - & 9.5 & 28.6 & 4.8 & 9.5 & - & 4.8 & - & - \\
\hline & $\mathrm{D}$ & 15.0 & 10.0 & - & 5.0 & 5.0 & 20.0 & - & - & - & - & 10.0 & 35.0 \\
\hline 日 & $\mathrm{E}$ & 5.1 & 2.6 & 5.1 & 10.3 & 10.3 & 25.5 & 2.6 & 7.7 & - & - & 10.3 & 20.5 \\
\hline の & $\mathrm{F}$ & 5.6 & 7.0 & 8.5 & 5.6 & 12.7 & 32.4 & 1.4 & 2.8 & - & - & 9.9 & 14.1 \\
\hline \multirow{3}{*}{ 分 } & $\mathrm{G}$ & 5.6 & 5.6 & - & 5.6 & - & - & 22.2 & 5.6 & 16.7 & - & 11.1 & 27.6 \\
\hline & $\mathrm{H}$ & 9.5 & - & - & 4.8 & 9.5 & 9.5 & - & 28.6 & - & 9.5 & 4. 8 & 23.8 \\
\hline & I & - & 28.5 & - & - & 14.3 & 14.3 & 14.3 & - & - & - & 14.3 & 14. 3 \\
\hline \multirow[t]{3}{*}{ 型 } & $\mathrm{J}$ & 10.0 & - & - & - & 10.0 & 10.0 & 10.0 & - & - & 10.0 & - & 50.0 \\
\hline & $\mathrm{X}$ & 8.0 & 4.0 & 2.0 & 6.0 & 10.0 & 12.0 & 4. & 6.0 & 4.0 & 6.0 & 16.0 & 42.0 \\
\hline & $\mathrm{O}$ & 3.8 & 1.3 & 0.6 & 2.5 & 3.2 & 7.0 & 1.9 & 1. 3 & - & - & 13.4 & 65.0 \\
\hline
\end{tabular}


のことから，I・J 型は移動速度の大きい低気圧に よる降雪分布型と推定できる.

次に，降雪分布型の連続の状態を調べた．第 2 表 は翌日の分布型の出現率を当日の分布型別に表わし たものである. 翌日においても当日と同じ分布型が 出現する頻度の最も高いのはA型で $40.0 \%$ である. 次いで $\mathrm{F}$ 型の $32.4 \%$ である. B・C・E型をみる と翌日 F 型の出現する確率が高くなっている. 地上 気圧配置型との関連でみると，I 型の出現頻度の高 いA〜 F 型は，翌日においても $\mathrm{A} \sim \mathrm{F}$ 型のいずれか の型をもつ場合が多く，特にEないしF型になりや すい. また，前日の分布型の出現頻度(第 3 表)をみ ると， B・C型は $\mathrm{E}$ 型ないしF型であることが多い． さらに，B型とC型とでは，翌日も同じ分布型とな る確率はC 型の方が $\mathrm{B}$ 型の場合よりも高い：これら のことから，B型と $\mathrm{C}$ 型は冬型の気圧配置を基本場 として，総観規模の天気図上に表われてこない小じ ょう乱によってもたらされる降雪分布型と考えられ る. しかし，両者の小心゙ょう乱の性格は異なってい ると考えてよいであろう.

\section{IV 降雪分布型と $850 \mathrm{mb}$ 面高度場の特徵との関係}

1)秋田における $850 \mathrm{mb}$ 面の風向・風速との対応 $850 \mathrm{mb}$ 面の気流の場は帯状雲発生の一次的支配 要因であり(川添, 1976), 冬季のレーダーエコーの 移動は $850 \mathrm{mb}$ 面の風に支配されている. また, 帯 a b
状雲の分布やエコーの分布は, 降雪分布との対応が あることが知られている(岡林，1972；三瓶・川添, 1976). 以上のことから, $850 \mathrm{mb}$ 面の気流の場と降 雪分布型との間に対応関係があることが期待される. そこで, 上層風の観測点として, 対象地域のほぼ中 央に位置する秋田を選び, 観測時刻 21 時の資料を 用いた. 秋田上空 $850 \mathrm{mb}$ 面の風と降雪分布型との 対応を表わしたのが第 4 図である. 図中には，各降 雪分布型の総出現日数に対して, $60 \%$ 以上の出現頻 度のあった範囲を示してある．D型については出現 日数が少ないので省略した.

第 4 図-a は東北地方南部に中心域をもつ C 型と $\mathrm{F}$ 型を示してある. $\mathrm{C}$ 型と $\mathrm{F}$ 型の風向は $270^{\circ} \sim 290^{\circ}$ (W-NW) で大きな差はない. 風速についてみると， 降雪分布の中心域は $10 \mathrm{~m} / \mathrm{sec}$ 以上の強風時には $\mathrm{F}$ 地域に, $10 \mathrm{~m} / \mathrm{sec}$ 以下の弱風時には海岸平野部であ るC地域にできる. 深石(1964)は新潟県における里 雪・山雪時の輪島の風速の比較から, ほぼ同様の結 果を得ている. 降雪分布からみても, C型は北陸地 方の里雪型に，F型は山雪型に連なる分布型と考え られる.

第 4 図-b は東北地方北部に降雪分布の中心域を もつB型と $\mathrm{E}$ 型を示す.この両分布型を比較すると， その風速においてはほとんど差は認められない. 大 部分のものが $10 \sim 15 \mathrm{~m} / \mathrm{sec}$ の風速である. しかし, 風向には大きな差が認められる. すなわち， $\mathrm{E}$ 型に c

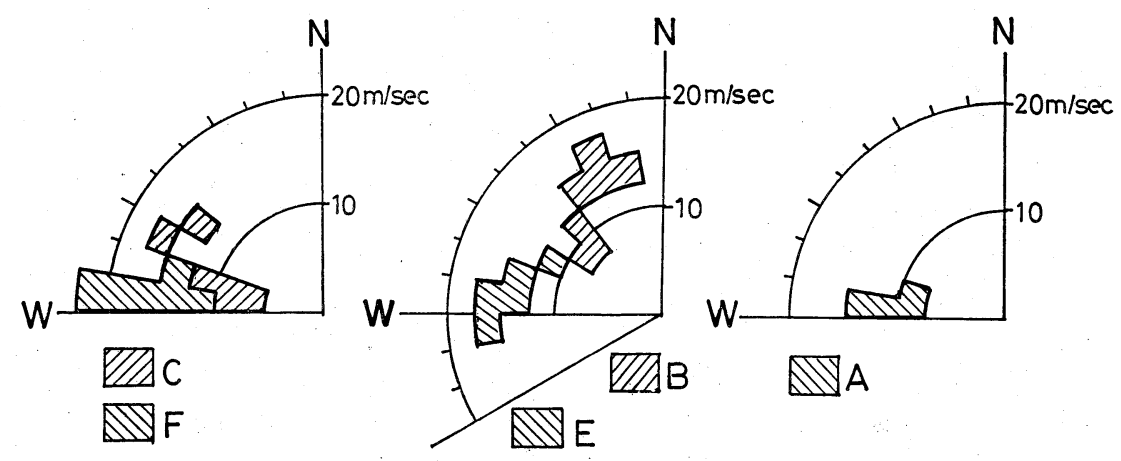

第 4 図降雪分布型と秋田における $850 \mathrm{mb}$ 面の風との対応 
おいては, $260^{\circ} \sim 300^{\circ}(\mathrm{W}-\mathrm{NW})$ であるのに対し， B型においては, $300^{\circ} \sim 350^{\circ}(\mathrm{NW}-\mathrm{N})$ である. B 型の風向は，秋田から横手へ伸びている中心域の走 向と一致している.

第 4 図-c は，青森県に降雪分布の中心域をもつ A 型の場合を示す．風速は $5 \sim 15 \mathrm{~m} / \mathrm{sec}$ で，風向は Wである.

E 型と $\mathrm{F}$ 型を比較すると，大きな差は認め難い.
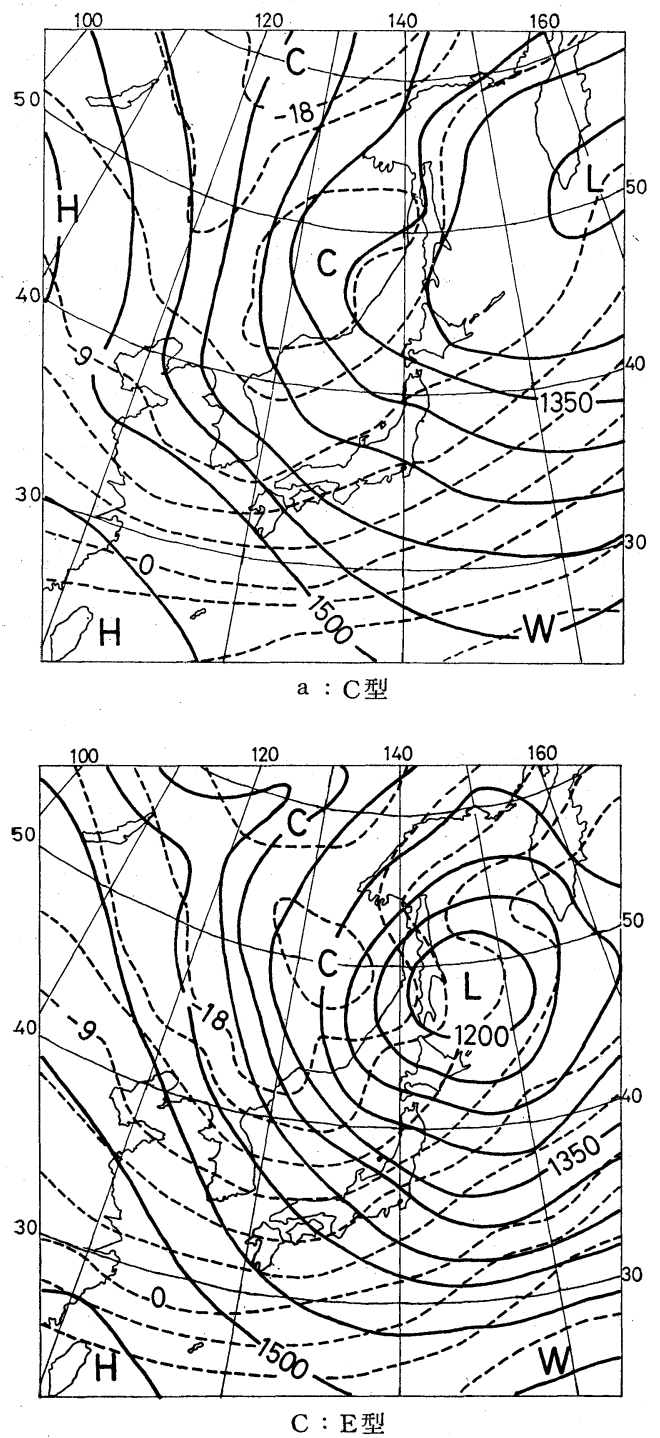

第 5 図 $850 \mathrm{mb}$ 面平均図

実線は等高線 $(\mathrm{gpm})$, 破線は等温線 $\left({ }^{\circ} \mathrm{C}\right)$ を表わす.
これは, 両者が基本的には山雪型の降雪であり, 降 雪分布型の差違はわずかな風向・風速の差で生じて いるためと考えられる.

2) $850 \mathrm{mb}$ 面天気図の特徵

以上のように，地上気圧配置型が I 型の時に出現 頻度の高い分布型と $850 \mathrm{mb}$ 面の風との間にはかな りよい対応が認められた：おのおのの分布型の中か ら代表的な分布をもつ日を抽出し, 日降雪量および
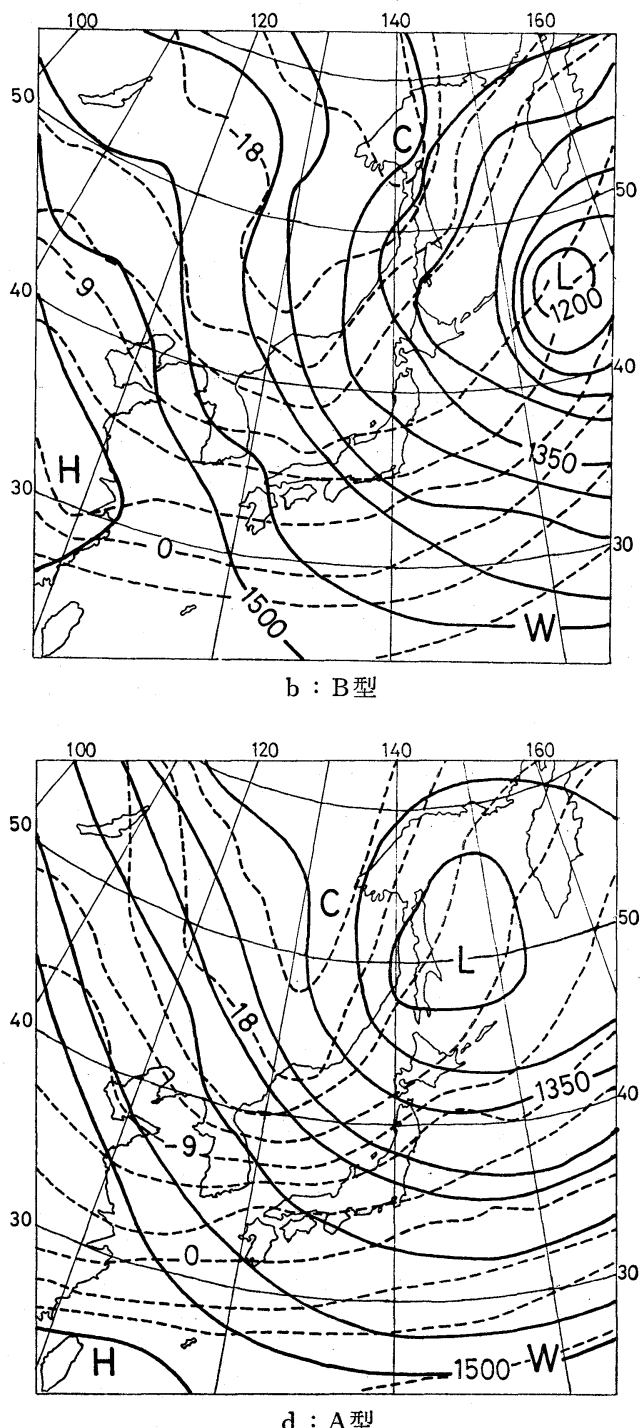

$\mathrm{d}: \mathrm{A}$ 型 
$850 \mathrm{mb}$ 面高度・気温の平均図を作成した. 例数は 10 ないし 20 例である.この図は気象庁発行の 850 $\mathrm{mb}$ 面天気図上に緯度・経度 $2.5^{\circ}$ のメッシュをか け，各格子点の值を読み取り，平均したものである. 高度分布は実線で $30 \mathrm{gpm}$ ごとに，気温分布は破線 で $3^{\circ} \mathrm{C} こ ゙ と に$ 示してある. 以下に $850 \mathrm{mb}$ 面の平均 図の特徴を降雪分布型別に記述する.

新潟県北部を中心域とするC型の場合について第 5 図-a に示す. 低気圧はカムチャツカ半島東部に 中心をもち，高圧部はバイカル湖の南と台湾付近に ある. 高圧部の間には，ボッ海から朝鮮半島北部に 伸びる気圧の谷が形成されている. 日本付近の気圧 傾度はゆるく，風向は北海道を除き北西である.こ の気圧分布は Fukuda(1965)の示した北陸地方の里 雪時の気圧分布のモデルと類似している. このこと から, C型の降雪機構は北陸地方の里雪の場合と類 似していると考えられる.

次に，秋田県平野部に中心域をもつB型の場合を 第 5 図-b に示す. 降雪分布の中心域は幅 $20 \mathrm{~km}$, 長さ $100 \mathrm{~km}$ の帯状をなし，秋田から横手方向へ伸 びている. $850 \mathrm{mb}$ 面の低気圧は北海道東方海上で, カムチャツカ半島の南方に中心をもっている. 一方, 高圧部は中国の中部から南東へ張り出している. 日 本付近の気圧傾度はゆるやかであり, 東北地方の気 流は北西から北の風である. この風向は降雪分布の 中心域の走向とよく一致している．秋田の大雪時に は，深浦沖に小じょう乱が発生し，850 mb 面の気 流によって移動することがレーダーエコーの観測か ら明らかにされている(佐々木，1975；三浦・村上， 1975). このことから，B型の降雪は，小じょう乱 が北西ないし北の風により秋田県を通過することに よると推定できる.

内陸に降雪分布の中心域をもつ分布型の例として 第 5 図-c にE型の $850 \mathrm{mb}$ 面平均図を示す. 中心 域は奥羽山脈の日本海側斜面に南北に伸び，その幅 は狭い. $850 \mathrm{mb}$ 面の低気圧は北海道北東海上にあ
り，中心は $1,230 \mathrm{gpm}$ と深い. 高圧部は 1,530 gpm の等高線でみると, 台湾北東沖に張り出してきてい る. 日本上空での気圧傾度は大きい. 大陸上の寒気 の南下の程度は大きく, 日本海北部に流出してきて いる.

$\mathrm{F}$ 型の場合の気圧分布は, $\mathrm{E}$ 型の場合と類似して おり，日本付近においてはE型のパターンがわずか に北東にずれた形となっている. 寒気の南下の状態 はE型とは異なり，日本海北部から中部を寒気が被 っている.

最後に, 第 5 図-d にA型の場合の $850 \mathrm{mb}$ 面平 均図を示す. A 型の中心域は青森を中心に東西に $70 \mathrm{~km}$ ，南北 $20 \mathrm{~km}$ の帯状をなしている. $850 \mathrm{mb}$ 面の低気圧は樺太の北東沖に，高圧部は台湾東沖に 現われている．気圧傾度は $\mathrm{C}$ 型と $\mathrm{E}$ 型の中ほどであ る. 東北地方の気流は, 中心域の走向と一致してお り, ほぼ西風である. 寒気の南下の程度も中程度で ある.

以上，降雪分布型別の特徴を述べてきたが，この 特徵をまとめると第 6 図のようになる. 図中には, $850 \mathrm{mb}$ 面平均図上での低気圧の中心位置および高 圧部 $(1,530 \mathrm{gpm}$ 以上)の出現位置を示した. さらに,

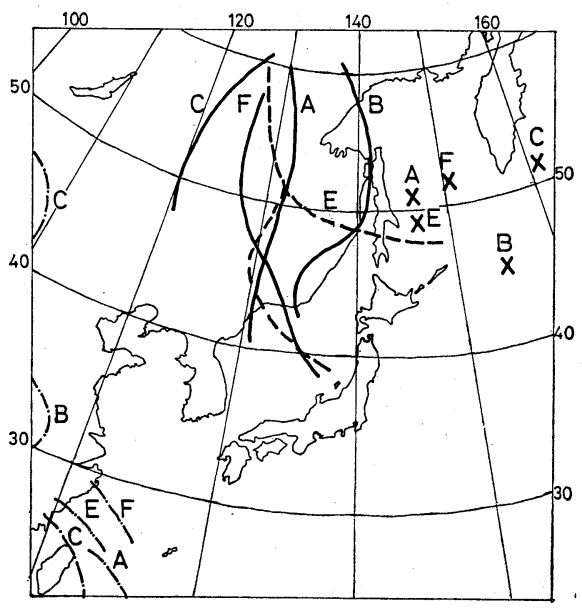

第 6 図 $850 \mathrm{mb}$ 面平均図に現われた降雪 分布型の特徵

.太線は寒気軸を, 細線は高圧部 $(1,530 \mathrm{gpm}$ の等 高線で示す)を, $\times は$ 低気圧中心を示す. 
寒気の状態を示すために寒気軸を示した．寒気軸は $8.50 \mathrm{mb}$ 面気温分布の谷線とし, その南限は $-15^{\circ} \mathrm{C}$ の等温線の位置とした.

低気圧中心と高圧部の位置によって，日本海海岸 部に中心域をもつ分布型 $(\mathrm{B} \cdot \mathrm{C}$ 型) と内陸部に中心 域をもつ分布型 $(E \cdot F$ 型) とに明瞭に分けられる. $\mathrm{E} \cdot \mathrm{F}$ 型の場合の低気圧の中心と高圧部は日本列島 に比較的近く位置し，気圧傾度は大きくなっている. B・C 型の低気圧中心はカムチャツカ半島に近く, 高圧部は中国大陸に現われる．特にC 型の場合の高 圧部の出現位置は北に偏っていて, 台湾付近の高圧 部との間に気圧の谷を形成している.

次に，寒気の状態について述べる. 気圧場と同じ く, 寒気の南下の状態は $\mathrm{B} \cdot \mathrm{C}$ 型と $\mathrm{E} ・ \mathrm{~F}$ 型とでは 異なっている. $\mathrm{B}$ 型では $140^{\circ} \mathrm{E}, \mathrm{C}$ 型では $120^{\circ} \mathrm{E}$ と寒気軸の位置は異なっているが, 寒気の南限は日 本海に達していない， E・F型では寒気の軸は $130^{\circ}$ Eにあり，寒気の南限は輪島沖に達していて，寒気 は日本海中・北部を被う形となっている. さらに, 降雪分布の中心域は寒気軸の延長上にあたっている. 以上のように，地上気圧配置型でみるならば，同 ビ西高東低の冬型気圧配置であっても，850 mb 面 の気圧場・気温場は，降雪分布型によって特徴ある パターンをもっている. 各降雪分布型における中心 域の降雪は, 地形による地上風の分布などの要因が 加わり，独自の降雪機構を正荐えられる.

3） $850 \mathrm{mb}$ 面低気圧の中心位置と太平洋側の降雪 分布型との対応

地上気圧配置型が低気圧型 (II 型) で出現頻度が高 くなる $\mathrm{G} \sim \mathrm{J}$ 型の $850 \mathrm{mb}$ 面の特徴について低気 圧の位置との関係で述べる. 第 7 図に $\mathrm{G} \sim \mathrm{J}$ 型の平 均日降雪量分布の中心域を示した。 具体的には $G$ ・ $\mathrm{H}$ ・J 型は $15 \mathrm{~cm}, \mathrm{I}$ 型については $20 \mathrm{~cm}$ の等値線 である. 第 8 図は $850 \mathrm{mb}$ 面平均図上での低気圧の 中心位置を示したものである. 低気圧の中心示度は いずれも約 $1,350 \mathrm{gpm}$ である. これらの図から各

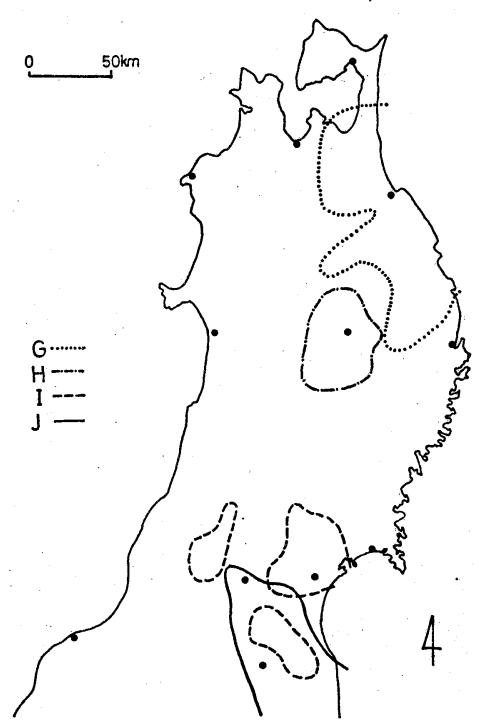

第 7 図降雪分布型 $G \sim J$ 型の中心域の位置 黑丸は気象官署を示す.

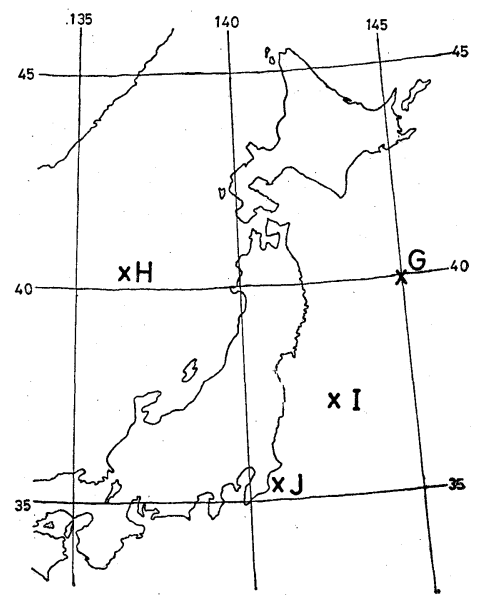

第 8 図降雪分布型 $G \sim J$ 型に対応する $850 \mathrm{mb}$ 面上の低気圧中心の位置

分布図の中心域に対応して低気圧中心の位置は定ま るといえる. すわなわち，中心域が最も南にある J 型に対応した低気圧中心の位置は関東地方海上に現 われる，この低気圧が，東進した場合には，降雪分 布の中心域はJ地域以北には広がらず，低気圧が遠 ざかるにつれて降水(雪)は減少する．低気圧が東北 地方の太平洋岸を北進すると，降雪分布の中心域も 北へ移動する．仙台が中心域に入る場合には宮城県 


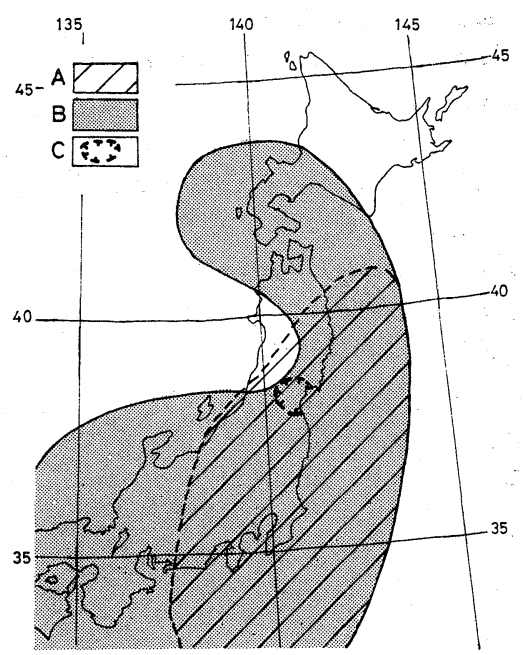

第 9 図 $850 \mathrm{mb}$ 面の上昇流域と湿潤域扰よび降 雪分布の中心域との関係 (1974 年 2 月 7 日 $\mathrm{J}$ 型の例）

$\mathrm{A}$ ：上昇流域 $\mathrm{B}$ ：湿潤域 $\mathrm{C}:$ 中心域.

南部沖に，八戸が中心域に入る場合には北部三陸沖 に低気圧の中心がある．これらの中心域はいずれも 山地の風上斜面にあたっている. I 型の中心域は仙 台平野と山形盆地の 2 つに分かれるが，これは仙台 西方の谷沿いに気流が山形盆地内へ吹きこむためと 考えられる. 盛岡が中心域となる場合には，日本海 上に低気圧の中心があり，東北地方上空の気流は南 西風となる. そのため北上低地の奥まで南の暖湿な 気流が入りやすくなっている.

降雪分布の中心域と低気圧の中心位置との間には 明らかな対応があるが，中心域の降雪が低気圧に寄 因する降雪であるとは断定しえない，そこで，低気 圧系にともなう暖気の移流によって生じる上昇流域 と降雪分布の中心域との位置関係を調べた. 1 例と して，1974年 2 月 7 日 ( $\mathrm{J}$ 型)の例を第 9 図に示す. 暖気の移流にともなう上昇流域は次式によって求め られる。

$$
\omega \propto-\boldsymbol{V}_{\mathrm{g}} \cdot \nabla\left(-\frac{\partial \theta}{\partial p}\right)
$$

ここで, $\theta$ は相当温位, $p$ は気圧を表わす. $V_{\mathrm{g}}$ は等 圧面に㧍ける地衡風であるが， $850 \mathrm{mb}$ 面の等高線
を地衡風の流線と近似した。また $(\partial \theta / \partial p)$ は 1,000 $\mathrm{mb}$ 面と $700 \mathrm{mb}$ 面との層厚で近似でき, 計算には 気像庁発行の地上天気図と $700 \mathrm{mb}$ 面天気図から,

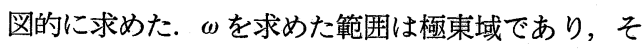
の一部を第 9 図は示している. 上式で求められる上 昇流の地域は大規模現象にともなう上昇流の大まか な近似である. 第 9 図には相対湿度 $85 \%$ 以上の地 域(湿潤域)と降雪分布の中心域を示してある. 降雪 分布の中心域は上昇流域と湿潤域が重合した地域に あたっている. $850 \mathrm{mb}$ 面の気温分布は図に示して いないが，中心域上空の $850 \mathrm{mb}$ 面の気温は約 $-10^{\circ} \mathrm{C}$ である. このような降雪分布の中心域と上 昇流域・湿潤域・気温分布との関係は, $\mathrm{G} \sim \mathrm{J}$ 型の 降雪分布型を示す他の日についても認められる.以 上の結果から, $\mathrm{G} \sim \mathrm{J}$ 型の降雪分布型の中心域の降 雪は，低気圧に原因する降雪であると考えられる.

$$
\mathbf{V} \text { ま め }
$$

東北地方の降雪分布図を多降雪日の出現の状態か ら分類した地域区分に基づいて, 中心域の属する地 区で分類した，降雪分布型と総観規模の天気図，特 に $850 \mathrm{mb}$ 面天気図との対応を調べた結果，次のこ とが明らかとなった。

1. 多降雪日の出現の状態によって, 10 地域に区 分できる. 日本海側平野部・内陸部はおのおの 3 地 域に細分される. 日本海側と太平洋側との境界は, 奥羽山脈を含む地域に明瞭に現われるが，秋田県・ 岩手県の北部県境では不明瞭である.また，山形盆 地は太平洋側の地域に属する.

2. 日本海側に中心域をもつ 5 つの分布型は，秋 田 $850 \mathrm{mb}$ 面の風向・風速と明瞭な対応があり, $850 \mathrm{mb}$ 面平均図においても明瞭な特徴をもってい る. 東北地方南部の平野部と内陸部の分布型はそれ ぞれ北陸地方の里雪・山雪時の天気図と類似の天気 図型をもち，その延長部分にあたると理解される。 北部平野部(秋田県平野部)の分布型は北陸地方の里 
雪とは異なる降雪機構をもつ.

3. 太平洋側に中心域をもつ分布型は, $850 \mathrm{mb}$ 面平均図上の低気圧中心の位置と密接に関係してい

る. 中心域の相違は低気圧中心の位置の違いによる. 上昇流域との関係から, 太平洋側の降雪分布型の中 心域の降雪は低気圧に原因する降雪であるといえる.

以上の結果から, 地形の影響などを加味するなら ば, 10 地域での降雪はおのおのその地域に独特の降 雪機構をもつ降雪であるといえる. 今回の研究は降 雪分布型と $850 \mathrm{mb}$ 面天気図との対応を調へたもの である. 今後, 各降雪分布型についてその降雪機構 を調査する必要があると思われる.

本論文を作成するにあたり, 終始御指導くださいまし た筑波大学地球科学系教授吉野正敏先生, 河村 武先生 ならびに同講師田宮兵衛先生に心から感謝いたします. また，有益な助言をくださった同大学院の方々に感謝い たします。

本稿は 1978 年度春季学術大会において発表したもの に加筆・訂正したものである.

(投稿 1978 年 5 月 25 日)

(受理 1978 年 10 月 7 日)

\section{文 献}

岡林俊雄 (1966)：高層状態のモデルと総観解析との 関係および北海道と北陸との降雪の差異. 天気, 13, $440 \sim 444$.

岡林俊雄 (1972)：気象衛星からみた雪雲と降雪につ いての研究への利用. 気象研究ノ一ト, 113 号, $74 \sim 106$.

川添信房 (1973)：北西季節風の大雪. 東北技術だよ り, 63 号, 1 38.

川添信房 (1976)：北西季節風時の帯状雲発生の総観 的条件について. 昭和 51 年度仙台管区調查研究 会資料，110 113.

菊地 挵 (1972) : 新庄と山形との冬期間の天気の差 違について. 気象庁研究時報, 24,523 526.

気象庁 (1968)：北陸豪雪調查報告. 気象庁技術報告, 66 号, 481 ページ.

工藤敏雄・中村憲司(1976) : 東北地方太平洋側の大 雪について(第一報). 昭和 51 年度仙台管区調査
研究会資料, 75 78.

佐々木耕造 (1971)：日降雪量の確率的表現について. 昭和 46 年度東北地方調査研究会資料, $3 \sim 4$.

佐々木芳春 (1975)：冬季深浦沖に発現するメソじょ う乱のレーダー解析. 昭和 50 年度東北地方調査 研究会資料, 116 118.

三瓶次郎・川添信房 (1976) : 冬季, 寒気ドームの通 過に伴う東北地方日本海側におけるレーダーエコ 一の形状と特性の変化. 気象庁研究時報, 28 , $189 \sim 200$.

田坂郁夫 (1977)：台湾低気圧と本邦の降水分布. 東 北地理, $29,101 \sim 108$.

長谷川徳太郎 (1949)：北海道西海岸に発生する副低 気圧に就いて. 中央気象台研究時報, 1, 207 211. 深石一夫 (1963)：新潟県の降雪分布 (1). 水温の研 究, 7, 185 191.

深石一夫 (1964)：新潟県の降雪分布 (3). 水温の研 究, 8, 295 299.

藤田敏夫 (1966)：北陸地方の里雪と山雪時における 総観場の特徵. 天気, 13，359 366.

三浦 勉・村上広蔵 (1975)：秋田レーダーによるメ ソ low について. 昭和 50 年度東北地方調查研究 会資料, $119 \sim 122$.

Fukuda, K. (1965): Synoptic study on the mechanism of heavy snowfall. Geophys. Mag., 32, 317 359.

Matsumoto, S., Ninomiya, K. and Akiyama, T. (1967): A synoptic and dynamic study on the three dimensional structure of mesoscale disturbances observed in the vicinity of a cold vortex center. J. Meteor. Soc. Japan, 45, 64 82.

Miyazawa, S. (1967): On vortical disturbances observed during the period of heavy snow or rain in the Hokuriku district. J. Meteor. Soc. Japan, 45, $166 \sim 176$.

Shitara, H. (1974): A climatological analysis of the weather distribution in Tohoku district in winter. Sci. Rep. Tohoku Univ., Ser. 7 (Geography), No. 15, 35 54.

Yoshino, M. M. and Kai, K. (1974): Pressure pattern calendar or East Asia, 1941-1970, and its climatological summary. Climatological Notes, No. 16, $71 \mathrm{p}$. 


\section{A SYNOPTIC STUDY ON DISTRIBUTION PATTERN OF DAILY DEPTH OF SNOWFALL IN THE TOHOKU REGION}

\section{Hiroyuki KUROSAKA*}

In order to study the geographical distribution of daily snowfall in the Tohoku region and its relation to synoptic weather conditions, the 10 district regions were first identified. All of these areas experience intense snowfall by either one of the three major types of snowfall. The first type of snowfall, defined by Types D, E and F occurs in the mountainous regions with the winter monsoons. The second type, defined by Types A, B and C occurs near Japan Sea coast. Finally the third type which is associated with cyclones is defined by Types G, H, I and J.

The study of synoptic conditions associated with snowfall types has shown distinct conditions for each of the three major types of snowfall. In the case of mountain snowfall, the wind at the 850-mb level over Akita was strong. The mechanism of the coastal snowfall was found to be different between the northern (Types A and B) and the southern (Type C) regions. In the southern regions, the wind at the $850-\mathrm{mb}$ level over Akita was weaker than $10 \mathrm{~m} / \mathrm{sec}$, but in the northern regions rather stronger. Hence, it can be concluded that the distribution type of snowfall in the southern region is similar to that occurred in the Hokuriku region. On the other hand, the distribution type of the coastal snowfall in the northern region appears to be unique to the Tohoku region. The third major type of snowfall which is associated with cyclones is characterized by the absence of cold air at the 850--mb level. In addition, the regionality of the snowfall occurred under the strong influence of the track of the cyclone.

As a result, each of the 10 region which was defined by the probability of the simultaneous occurrence of intense-snowfall day, may possess distinct characteristics in addition to the common characteristics associated with one of the three major types of snowfall in the Tohoku region. 